\title{
High glucose induces the aging of mesenchymal stem cells via Akt/mTOR signaling
}

\author{
DAYONG ZHANG ${ }^{1}$, HUIFEI LU ${ }^{1}$, ZHONGXING CHEN $^{1}$, YAYAN WANG ${ }^{1}$, JIUZHOU LIN $^{1}$, SHAN XU $^{1}$, \\ CHONG ZHANG $^{1}$, BAOMING WANG $^{1}$, ZHANGGEN YUAN $^{1}$, XIAO FENG $^{2}$, XUEFAN JIANG $^{3}$ and JIANPING PAN ${ }^{1}$ \\ ${ }^{1}$ Department of Clinical Medicine, Zhejiang University City College School of Medicine; \\ ${ }^{2}$ Clinical Laboratory, The Second People's Hospital of Hangzhou, Hangzhou, Zhejiang 310015; \\ ${ }^{3}$ Department of Otorhinolaryngology, Zhejiang Provincial People's Hospital, Hangzhou, Zhejiang 310014, P.R. China
}

Received March 1, 2016; Accepted February 23, 2017

DOI: $10.3892 / \mathrm{mmr} .2017 .6832$

\begin{abstract}
It has previously been demonstrated that glucose is important in the process of stem cell aging. However, the mechanisms of cell senescence induced by high glucose (HG) remain to be elucidated. The preliminary study indicated that D-galactose induced mesenchymal stem cell (MSCs) aging. The present study demonstrated, following treatment with 11.0 or $22.0 \mathrm{mM} \mathrm{HG}$ for 14 days, that HG significantly promoted MSCs aging and the expression levels of phosphorylated (p-)phosphatidylinositol 3-kinase/protein kinase B (Akt) and p-mammalian target of rapamycin signaling (mTOR) in the HG groups were increased compared with the control group. However, following Akt inhibition with 1.0 or $10.0 \mathrm{nM}$ MK-2206, which is an Akt-specific small molecule inhibitor, the senescence-cell value in the HG group was significantly decreased compared with the control group. These results indicated that HG induced MSCs senescence and this effect was primarily mediated via the Akt/mTOR signaling pathway.
\end{abstract}

\section{Introduction}

Stem cells reside in adult mammalian tissue, where they maintain normal tissue homeostasis and participate in tissue repair and regeneration in response to damage $(1,2)$. Mesenchymal stem cells (MSCs) are multipotent stem cells that may be isolated from bone marrow and other tissues $(3,4)$. These cells exhibit the ability to differentiate into a wide variety of tissue cell

Correspondence to: Mr. Xuefan Jiang, Department of Otorhinolaryngology, Zhejiang Provincial People's Hospital, 158 Shangtang Road, Hangzhou, Zhejiang 310014, P.R. China E-mail: jiangxuefan1@163.com

Professor Jianping Pan, Department of Clinical Medicine, Zhejiang University City College School of Medicine, 51 Huzhou Street, Hangzhou, Zhejiang 310015, P.R. China

E-mail:jppan@zucc.edu.cn

Key words: mesenchymal stem cells, aging, glucose, phosphatidylinositol 3-kinase/Akt and mammalian target of rapamycin signaling types. Furthermore, MSCs exhibit site-specific differentiation, responding to environmental cues and adapting their functions to diverse biomolecular contexts, therefore, MSCs are considered a reliable cell source for stem cell transplantation and are currently being tested in numerous ongoing clinical trials $(5,6)$. Previous studies have reported that MSC function declines with age and that MSC dysfunction influences the effects of autologous MSC transplantation in these individuals (7-9). The authors previously demonstrated that MSC aging may be induced by old rat serum (10). Therefore, investigation of the factors that affect MSC aging is of primary concern.

Numerous studies have demonstrated that glucose is an important regulator of cell senescence $(11,12)$. As a systemic milieu (13), blood glucose is important in the functioning of stem cells (14). A previous study indicated that hyperglycemia impairs bone marrow hematopoietic function and alters the hematopoietic niche (15). Diabetes has previously been reported to alter chemokine expression in MSCs (16). MSCs cultured in medium containing high glucose (HG) concentrations exhibit premature senescence, genomic instability and telomere alterations (17-19) however, the molecular promotive mechanisms of HG in stem cell aging remain to be elucidated.

It has previously been demonstrated that phosphatidylinositol 3-kinase (PI3K)/Akt and mammalian target of rapamycin (mTOR) are associated with stem cell aging $(20,21)$. The preliminary study indicated that activated Akt/mTOR is an important mediator in MSC aging (22). Notably, it has additionally been reported that high glucose activates the PI3K/Akt signaling pathway in podocytes (23), vascular smooth muscle cells (24) and vascular endothelial cells (25). Therefore, the present study aimed to investigate if $\mathrm{HG}$ induces MSC aging via the Akt/mTOR pathway. It has previously been demonstrated that HG promotes cellular aging, however the molecular mechanisms by which coenzyme Q10 modulates reactive oxygen species generation and stem cell aging remain to be elucidated. The results of the present study demonstrated that HG induced MSC senescence and Akt/mTOR signaling mediated this effect.

\section{Materials and methods}

Isolation and culture of MSCs. Sprague-Dawley (SD) rats (weight, 10.0-15.0 g; age, 7 days; male, $n=30$; female, $n=30$; 
total $n=60)$ were obtained from Zhejiang Medical Academy of Science (Hangzhou, China; permit number SCXK (Zhejiang) 2008-0033) and housed separately at $20-25^{\circ} \mathrm{C}$ under a $12-\mathrm{h}$ light/dark cycle and fed ad libitum with a normal diet. The investigation was permitted by the Law of the People's Republic of China on the Protection of Wildlife and the protocol was approved by the Ethical Committee of the Zhejiang University City College (Hangzhou, China). SD rats were sacrificed by cervical dislocation sacrificed by cervical dislocation and immersed in $75 \%$ alcohol and disinfectant for $3 \mathrm{~min}$. The rats were subsequently transferred to a new dish and the whole skin was removed from the hind limbs and forelimbs. The femurs and tibias were removed from the SD rats and bone marrow was flushed out using $10 \mathrm{ml}$ PBS with $100 \mathrm{U} / \mathrm{ml}$ heparin in a syringe. The cells were centrifuged at $110 \mathrm{x} \mathrm{g}$ at room temperature for $8 \mathrm{~min}$. The cell pellet was resuspended in $2.5 \mathrm{ml}$ Dulbecco's modified Eagle's medium (DMEM; Gibco; Thermo Fisher Scientific, Inc., Waltham, MA, USA) supplemented with $10 \%$ fetal bovine serum (FBS; Hangzhou Sijiqing Biological Engineering Materials Co., Ltd., Hangzhou, China) and plated in a $25 \mathrm{~cm}^{2}$ plastic flask (Corning Incorporated, Corning, NY, USA) to allow the MSCs to adhere at $37^{\circ} \mathrm{C}$ with $5 \% \mathrm{CO}_{2}$ in a humidified atmosphere. Following a 3 day period, the medium was replaced and the nonadherent cells were discarded. The medium was completely replaced every 3 days thereafter. The cells became $\sim 80 \%$ confluent at 7-10 days following seeding. The adherent cells were released from the dishes with $0.25 \%$ trypsin (Hyclone; GE Healthcare Life Sciences, Logan, UT, USA) and seeded into fresh culture flasks. All the experiments described below were performed using MSCs from the third to the fifth passages.

Treatment methods of MSCs. In the control groups, MSCs were cultured for 14 days in DMEM supplemented with 10\% FBS. In the glucose treatment groups: MSCs were incubated in the culture medium containing $5.5,11.0$ or $22.0 \mathrm{mM}$ glucose for 14 days. In the high glucose control group, MSCs were treated with $22.0 \mathrm{mM}$ glucose for 14 days to induce cellular senescence. In the MK-2206 treatment group, the cells were incubated in the culture medium containing $0.1,1.0$ or $10.0 \mathrm{nM}$ MK-2206 and $22.0 \mathrm{mM}$ glucose for 14 days. The medium was completely replaced every 3 days. The cells of all of the above groups were cultured in a humidified incubator at $37^{\circ} \mathrm{C}$ and $5 \% \mathrm{CO}_{2}$.

Senescence-associated $\beta$-galactosidase (SA- $\beta$-gal) staining. SA- $\beta$-gal staining was performed using a Senescence-associated $\beta$-Galactosidase Staining kit (Beyotime Institute of Biotechnology, Haimen, China) following the manufacturer's protocol. The treatment methods for the MSCs in each group were the same as the aforementioned. The cells were fixed in $4 \%$ $(\mathrm{v} / \mathrm{v})$ formaldehyde for $5 \mathrm{~min}$ and were then stained with SA- $\beta$-gal staining solution at $\mathrm{pH} 6.0$ for $12 \mathrm{~h}$. The SA- $\beta$-gal-positive cells exhibited a blue coloration. The number of positive cells were counted under a phase-contrast microscope. The experiment was repeated five times in each group.

Sulforhodamine B (SRB) assay. Briefly, cells were fixed with $10 \%$ trichloroacetic acid solution for $1 \mathrm{~h}$, wells were rinsed five times with tap water and then cells were stained with $0.4 \%$ SRB solution (100 $\mu \mathrm{l}$ per well) for $20 \mathrm{~min}$ at room temperature. The wells were then rinsed with $1 \%$ acetic acid to remove unbound dye and were left to air dry. The SRB dye was then solubilized by placing $100 \mu \mathrm{l}$ unbuffered Tris-based solution in each well, and the absorbance was measured at a wavelength of $515 \mathrm{~nm}$ using a multiscan spectrum. The experiment was repeated five times in each group.

Western blot analysis. To assay the expression of phosphorylated (p)-16 ${ }^{\mathrm{INK} 4 \mathrm{a}}, \mathrm{p} 53, \mathrm{p} 21, \mathrm{p}-\mathrm{mTOR}, \mathrm{p}-\mathrm{Akt}, \mathrm{p}$-glycogen synthases kinase (GSK)-3 $\beta$ and $\beta$-catenin, the total cellular protein was extracted from MSCs from different treatment groups. The cells were first washed in cold-buffered PBS and lysed in radioimmunoprecipitation assay buffer (150 mM NaCl, 1\% Triton X-100, 0.5\% NaDOD, 0.1\% SDS and $50 \mathrm{mM}$ Tris, $\mathrm{pH} 8.0$ ). Following centrifugation (9660 x g for $5 \mathrm{~min}$ ) at $4^{\circ} \mathrm{C}$, the protein supernatant was transferred into different tubes. The protein concentration of the samples was determined using a bicinchoninic acid protein assay (Beyotime Institute of Biotechnology). A $40 \mu \mathrm{g}$ sample of the total protein was resolved using $8-12 \%$ SDS-PAGE and transferred onto polyvinylidene difluoride (EMD Millipore, Billerica, MA, USA) membranes. The membranes were blocked with 5\% nonfat milk at room temperature for $1 \mathrm{~h}$ in Tris-buffered saline containing Tween-20 (TBST) and incubated overnight at $4^{\circ} \mathrm{C}$ with the following Primary antibodies: rabbit anti-p16 ${ }^{\text {INK4a }}(1: 1,000$; cat. no. sc-1661; Santa Cruz Biotechnology, Inc., Dallas, TX, USA), mouse anti-p53 (1:2,000; cat. no. 554147; BD Biosciences, Franklin Lakes, NJ, USA), mouse anti-p21 (1:1,000; cat. no. sc-6246; Santa Cruz Biotechnology, Inc.), rabbit anti-p-mTOR (1:2,000; Ser2448; cat. no. 2971S; Cell Signaling Technology, Inc., Danvers, MA, USA), rabbit anti-p-Akt (1:2,000; Ser473; cat. no. 4058S; Cell Signaling Technology, Inc.), rabbit anti-p-GSK-3 $\beta$ (1:2,000; Ser9; cat. no. 5558; Cell Signaling Technology, Inc.), mouse anti- $\beta$-catenin $(1: 1,000$; cat. no. sc-7963; Santa Cruz Biotechnology, Inc.) and mouse anti- $\beta$-actin (1:5,000; cat. no. 612657; BD Biosciences), were incubated overnight with the membranes at $4^{\circ} \mathrm{C}$. Membranes were incubated with horseradish peroxidase (HRP)-conjugated anti-rabbit or anti-mouse secondary antibodies (1:2,000; cat. nos. 7074 and 7076; Cell Signaling Technology, Inc.) for $1 \mathrm{~h}$ at room temperature, and proteins were detected by enhanced chemiluminescence (cat. no. RPN2106; GE Healthcare Life Sciences, Little Chalfont, UK). $\beta$-Actin was used as the internal control to normalize the loading materials.

Statistical analysis. All data are presented as the mean \pm standard deviation. Statistical significance was determined using one-way analysis of variance to compare data from different experimental groups, followed by the Student-Newman-Keuls multiple comparison test. SPSS software, version 11.5 (SPSS, Inc., Chicago, IL, USA) was used to process data. $\mathrm{P}<0.05$ was considered to indicate a statistically significant difference.

\section{Results}

$H G$ promotes MSCs senescence. SA- $\beta$-gal staining was used to observe the effect of HG on MSCs aging. The results demonstrated that SA- $\beta$-gal-positive cells appeared larger and 
A

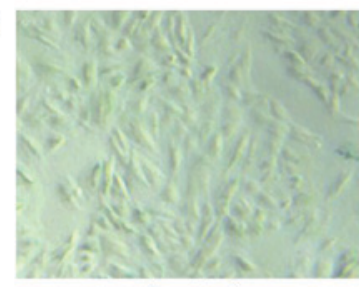

Control

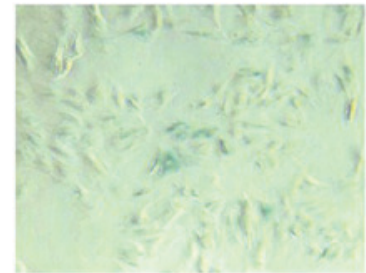

$11.0 \mathrm{mM}$ glucose

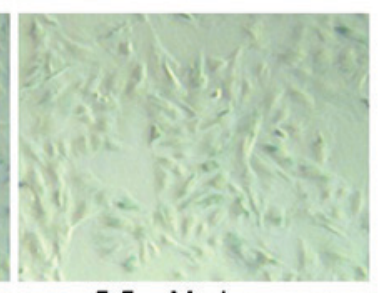

$5.5 \mathrm{mM}$ glucose

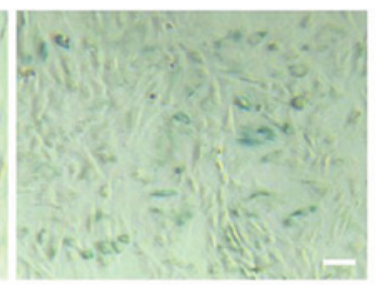

$22.0 \mathrm{mM}$ glucose
B

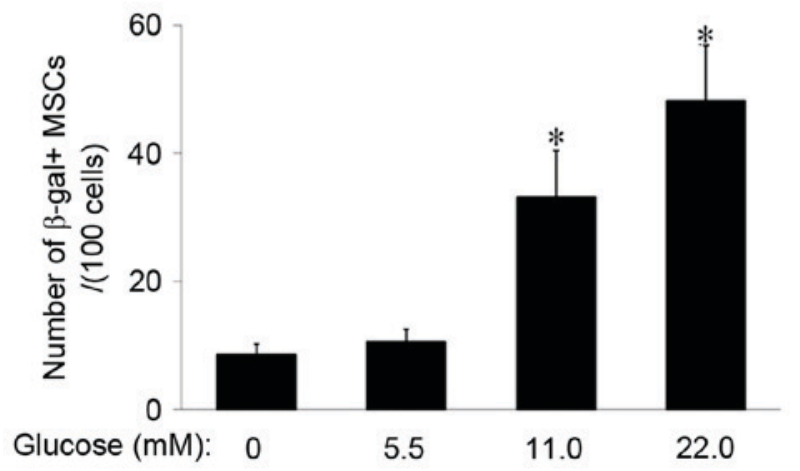

Figure 1. Effect of different concentrations of glucose on MSCs senescence. (A) SA- $\beta$-gal staining. The number of SA- $\beta$-gal-positive cells in the $11.0 \mathrm{mM}$ and $22.0 \mathrm{mM}$ glucose groups increased compared with the control group. SA- $\beta$-gal-positive cells exhibit a flat and enlarged cell shape. Scale bar, $25 \mu \mathrm{m}$. (B) Quantification of SA- $\beta$-gal-positive cells. The total number of SA- $\beta$-gal-positive cells of 100 random cells was counted using phase-contrast microscopy. The results demonstrated that the number of SA- $\beta$-gal-positive $\mathrm{MSCs} / 100$ cells in the 11.0 and $22.0 \mathrm{mM}$ glucose group was significantly increased compared with the control group. ${ }^{*} \mathrm{P}<0.01$ vs. control; $\mathrm{n}=5$. MSCs, mesenchymal stem cells; SA- $\beta$-gal, senescence-associated $\beta$-galactosidase.

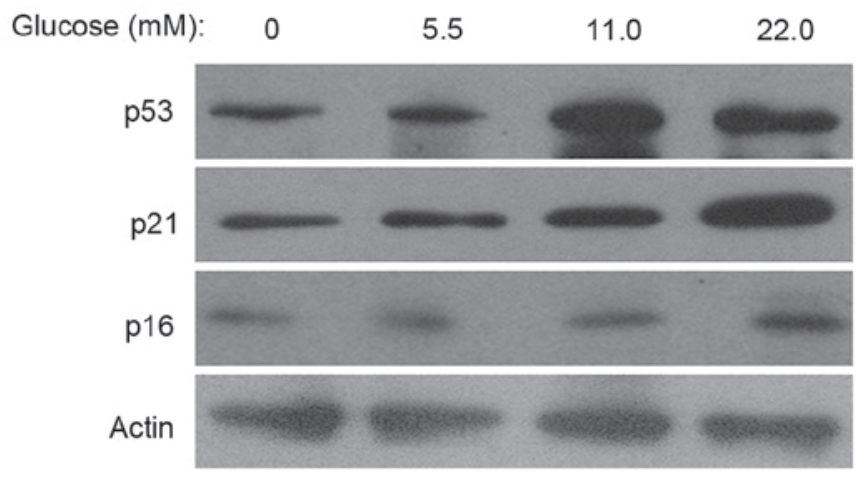

Figure 2. Effects of differing concentrations of glucose on the expression of senescence-associated proteins in mesenchymal stem cells. The protein expression levels of $\mathrm{p} 53, \mathrm{p} 21, \mathrm{p} 16^{\mathrm{INK} 4 \mathrm{a}}$ were analyzed via western blotting. $\beta$-actin served as the internal control. The p53, p21 and p16 ${ }^{\mathrm{INK} 4 \mathrm{a}}$ expression levels increased in the 11.0 or $22.0 \mathrm{mM}$ glucose groups compared with the control group.

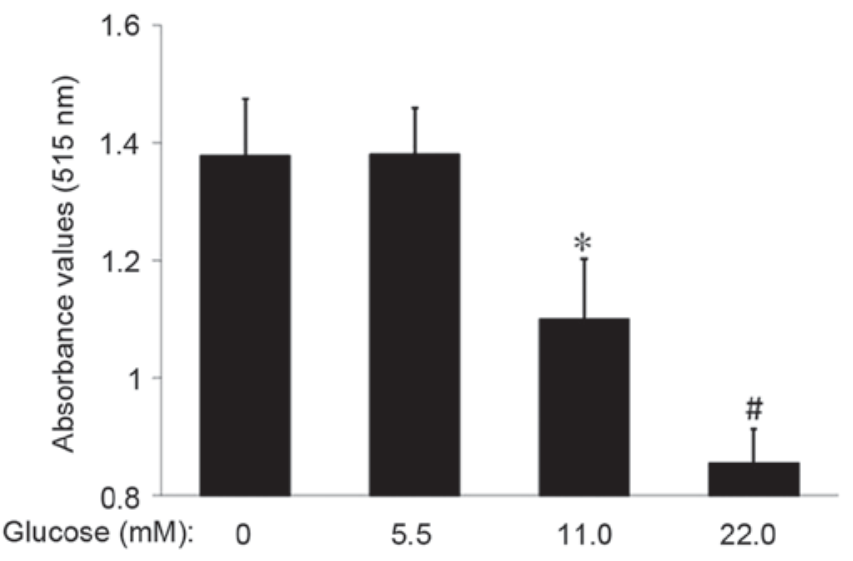

Figure 3. Effect of differing concentrations of glucose on MSC proliferation. MSCs were washed and incubated in medium containing various concentrations of glucose for 14 days. Absorbance value was significantly decreased in the 11.0 and the $22.0 \mathrm{mM}$ glucose groups compared with the control group. ${ }^{*} \mathrm{P}<0.05,{ }^{\#} \mathrm{P}<0.01$. control; $\mathrm{n}=5$. MSCs, mesenchymal stem cells.

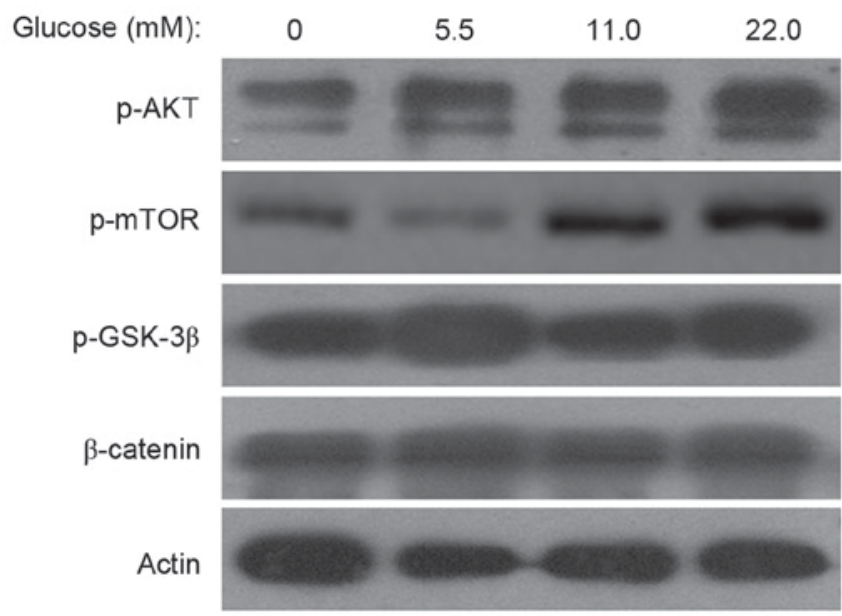

Figure 4. Effects of high glucose on the Akt/mTOR and Wnt/ $\beta$-catenin pathway. A total of 14 days following incubation in differing concentrations of glucose, cell lysates were prepared for western blot analysis. The protein expression levels of $\mathrm{p}$-mTOR and p-Akt were increased in the 11.0 and $22.0 \mathrm{mM}$ glucose groups compared with control group, however, the expression levels of p-GSK-3 $\beta$ and $\beta$-catenin in the two HG treatment groups appeared to remain unaffected. $\beta$-actin served as the internal control. p-, phosphorylated; Akt, protein kinase B; mTOR, mammalian target of rapamycin signaling; GSK, glycogen synthase kinase.

of a flatter shape and notably, few SA- $\beta$-gal-positive cells were observed to be present in the control group. However, in the 11.0 and $22.0 \mathrm{mM}$ glucose groups, the number of SA- $\beta$-gal-positive cells increased (Fig. 1A). The cell counting indicated that the number of SA- $\beta$-gal-positive cells in the $11.0 \mathrm{mM}$ and $22.0 \mathrm{mM}$ glucose group (33.2 \pm 7.3 and $48.2 \pm 8.6 / 100$ cells, respectively) were significantly increased compared with the control group (8.6 \pm 1.7 ; $\mathrm{P}<0.01$; Fig. 1B), which suggested that HG promoted MSCs senescence.

$H G$ induces the expression of p16 ${ }^{I N K 4 a}, p 53$ and p21 in MSCs. To investigate the effects of $\mathrm{HG}$ on the expression of senescence-associated proteins, the present study examined $\mathrm{p} 16^{\mathrm{INK} 4 \mathrm{a}}$, p53 and p21 expression levels via western blot analysis. The results demonstrated that, following cell culture in 11.0 or 


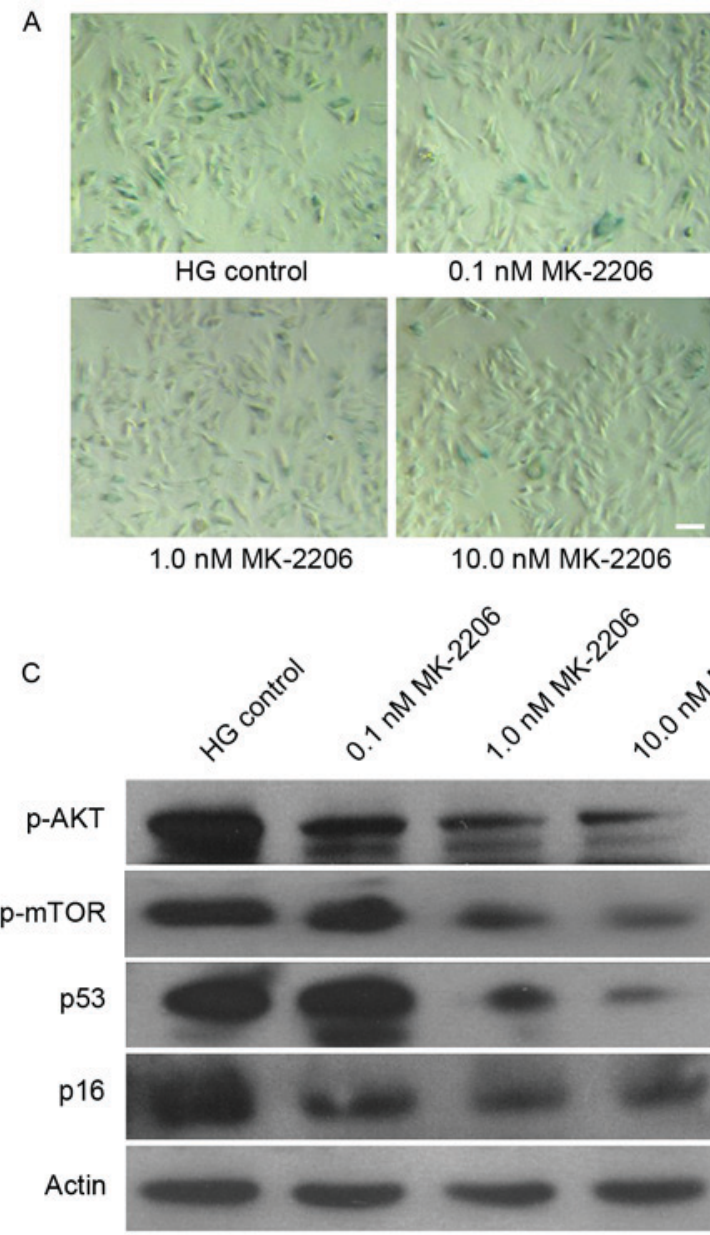

B

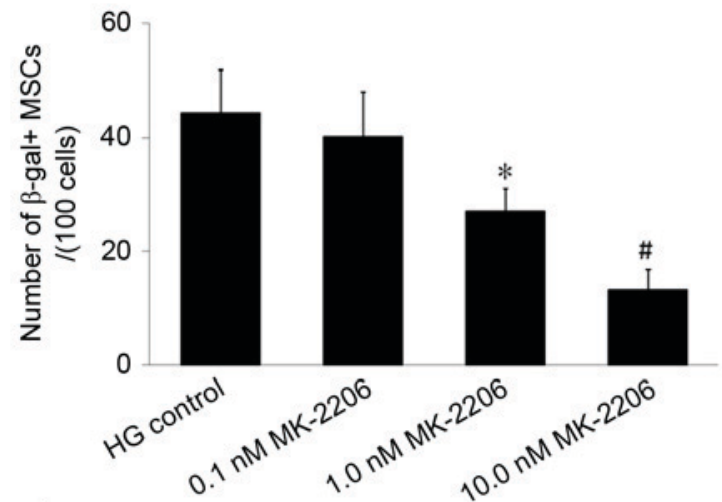

Figure 5. Effects of differing concentrations of MK-2206 on HG-induced MSCs senescence. (A) SA- $\beta$-gal staining. In the 1.0 and $10.0 \mathrm{nM}$ MK-2206 groups, the number of SA- $\beta$-gal-positive cells was decreased compared with that in the HG control group. Scale bar, $25 \mu \mathrm{m}$. (B) Quantification of SA- $\beta$-gal-positive cells. The total number of SA- $\beta$-gal-positive cells among 100 random cells was counted using phase-contrast microscopy. The results demonstrated that the number of SA- $\beta$-gal-positive MSCs/100 cells in the $1.0 \mathrm{nM}$ and the $10.0 \mathrm{nM} \mathrm{MK-2206}$ groups was decreased compared with HG control group. (C) Western blot analysis. The p-Akt and p-mTOR expression levels were decreased in the 1.0 and $10.0 \mathrm{nM} \mathrm{MK}-2206$ groups compared with the HG control group. Furthermore, the 53 and $\mathrm{p} 16^{\mathrm{INK} 4 \mathrm{a}}$ expression was decreased in the 1.0 and $10.0 \mathrm{nM} \mathrm{MK}-2206$ groups compared with HG control group. $\beta$-actin served as the internal control. ${ }^{*} \mathrm{P}<0.05,{ }^{,} \mathrm{P}<0.01$ vs. HG control; $\mathrm{n}=5$. HG, high glucose; SA- $\beta$-gal-positive, senescence-associated $\beta$-galactosidase-positive; MSCs, mesenchymal stem cells; p-, phosphorylated; Akt, protein kinase B; mTOR, mammalian target of rapamycin signaling.

$22.0 \mathrm{mM}$ glucose for 14 days, the expression levels of $\mathrm{p} 16^{\mathrm{INK} 4 \mathrm{a}}$, p53 and p21 were increased compared with the control group (Fig. 2). The results suggested that $\mathrm{p} 53 / \mathrm{p} 21$ and $\mathrm{p} 16^{\mathrm{INK} 4 \mathrm{a}}$ acted as potential mediators in MSC senescence, induced by HG.

$H G$ inhibits MSC proliferation. The proliferation rate of MSCs in each group was examined via the SRB assay. Following MSC incubation with 11.0 or $22.0 \mathrm{mM}$ glucose for 14 days, the absorbance value in the $11.0 \mathrm{mM}$ and $22.0 \mathrm{mM}$ glucose groups was decreased compared with the control $(1.10 \pm 0.10$ or $0.85 \pm 0.06$ vs. $1.38 \pm 0.10 ; \mathrm{P}<0.05$ or $\mathrm{P}<0.01$; Fig. 3 ). These data suggested that HG inhibited the proliferation of MSCs.

$H G$ increases the expression of $p$-Akt and $p$-mTOR in MSCs. To investigate the mechanisms of MSC senescence induced by $\mathrm{HG}$, the expression levels of p-mTOR, p-Akt, p-GSK- $3 \beta$ and $\beta$-catenin were examined. Western blot analyses indicated that the p-mTOR and p-Akt expression levels were increased in the $11.0 \mathrm{mM}$ or $22.0 \mathrm{mM}$ glucose groups compared with the control group and HG did not affect the expression of p-GSK-3 $\beta$ and $\beta$-catenin (Fig. 4).
These results indicated that $\mathrm{HG}$ activated the Akt/m-TOR signaling pathway in MSCs.

Akt/mTOR signaling is important in MSC senescence induced by $H G$. To further define the role of Akt/mTOR signaling in MSC senescence promoted by HG, MK-2206, an Akt-specific small molecule inhibitor, was used to inhibit the Akt/mTOR signaling. SA- $\beta$-gal staining demonstrated that the number of SA- $\beta$-gal-positive cells in the 0.1, 1.0 and $10.0 \mathrm{nM}$ MK-2206 groups decreased in a dose-dependent manner, compared with the HG control group (Fig. 5A). The cell count revealed that the number of SA- $\beta$-gal-positive cells in the 1.0 and $10.0 \mathrm{nM}$ MK-2206 groups (27.1 \pm 4.0 and $13.2 \pm 3.7 / 100$ cells) was significantly decreased compared with the glucose control group (44.3 $\pm 7.7 / 100$ cells; $\mathrm{P}<0.05$ or $\mathrm{P}<0.01$; Fig. 5B). Western blot analyses indicated that MK-2206 inhibited the expression of p-Akt, and furthermore the enhancing effects of HG on p53 and $16^{\mathrm{INK} 4 \mathrm{a}}$ expression levels were reversed by incubation with MK-2206 (Fig. 5C). These data indicated that the Akt $/ \mathrm{mTOR}$ signaling pathway was important in the MSC senescence induced by HG. 


\section{Discussion}

MSCs are of interest for potential future clinical applications as they exhibit numerous advantages for cell therapy, including multilineage differentiation, homing, immune modulation and wound-healing effects (26). However, increasing studies have demonstrated the aging of MSCs affects their clinical application $(27,28)$. It is important to identify the specific factors and regulatory mechanisms associated with MSC aging. Hyperglycemia due to diabetes mellitus and metabolic syndrome is an increasingly occurring health issue that may result in stem cell dysfunction $(29,30)$. Previous reports indicate that hyperglycemia impairs bone marrow hematopoietic functionality and alters the hematopoietic niche (31) and MSCs cultured in HG-medium have been demonstrated to exhibit premature senescence and telomere alterations $(17,18,32)$. However, due to the rapid rise in diabetes prevalence, further experimental evidence is necessary to identify the association between $\mathrm{HG}$ and stem cell senescence, particularly regarding MSCs. The present study investigated the effects of $\mathrm{HG}$ on MSC senescence and proliferation and the results demonstrated that HG (22.0 mM) increased expression of p53, p21 and $\mathrm{p} 16^{\mathrm{INK} 4 \mathrm{a}}$, which was associated with development of cell senescence and inhibition MSC proliferation.

It has previously been demonstrated that $\mathrm{HG}$ is a primary factor in stem cell aging, however, the mechanisms by which HG induces stem cell aging remain to be elucidated. It has been previously demonstrated that the Akt/mTOR and Wnt/ $\beta$-catenin signaling pathways are important in MSC senescence $(10,22,33)$, and further studies indicated that the $\mathrm{Akt} / \mathrm{mTOR}$ or $\mathrm{Wnt} / \beta$-catenin signaling pathways may be activated by $\mathrm{HG}$ in mesangial (34) or dendritic cells (35). Therefore, the present study hypothesized that HG may promote MSC senescence via the Akt/mTOR or Wnt $/ \beta$-catenin signaling pathways. The results demonstrated that the expression of p-Akt and p-mTOR were significantly increased in the $22.0 \mathrm{mM}$ glucose group compared with control group, however these effects did not appear to have been demonstrated on observation of phosphorylated GSK-3 $\beta$ and $\beta$-catenin levels. To further define the role of Akt/mTOR signaling in MSC senescence induced by HG, the present study used MK-2206, which is an Akt-specific small molecule inhibitor, to inhibit Akt/mTOR signaling and examine if inhibition of Akt alone was sufficient to reverse the promotive effect of HG on MSC senescence. The results indicated that MK-2206 significantly decreased the total number of SA- $\beta$-gal-positive cells and the expression of $\mathrm{p} 53$ and $\mathrm{p} 16^{\mathrm{INK} 4 \mathrm{a}}$ was additionally decreased in the 1.0 and $10.0 \mathrm{nM}$ MK-2206 groups compared with the HG control group. These results indicated that the Akt/mTOR signaling pathway acted as a primary mediator of the MSC senescence induced by HG.

In conclusion, the present study demonstrated that $\mathrm{HG}$ increased the number of SA- $\beta$-gal-positive MSCs and the levels of p53,p21 and p16 ${ }^{\mathrm{INK} 4 \mathrm{a}}$. A high concentration of glucose promoted MSC aging and inhibited MSC proliferation. The Akt/mTOR signaling pathway may act as the primary mediator of HG-induced MSC senescence.

MSCs may be induced to form spheroid islet-like clusters containing insulin producing cells (IPCs) (36), and MSCs from patients with type 1 and 2 diabetes may differentiate into IPCs (37). Although the high differentiation potential of embryonic stem cells and induced pluripotent stem cells surpasses that of MSCs, the latter have remained favorable for transplantation studies as MSCs are considered to be easily obtained from adult tissues, and exhibit immunodulatory and immunosuppressive properties, in addition to nontumorigenic differentiation potential (38). Therefore, MSCs have emerged as a better source for the generation of surrogate $\beta$ cells $(5,39)$. However, a number of studies have demonstrated that the hyperglycemic state in patients with diabetes may impair MSC function $(40,41)$; the results of the present study indicated that cellular senescence may be one of the causes of this phenomenon. Further deciphering of the specific underlying molecular mechanisms of HG involvement in MSC aging will provide an effective intervention target for delaying MSC aging and improving the efficacy of stem cell transplantation in diabetes.

\section{Acknowledgements}

The present study was supported by Zhejiang Provincial Foundation of National Science (grant nos. LY17H250001 and LY13H160030), Scientific and Technological Developing Scheme of Hangzhou (grant nos. 20130633B33 and 20130633B34), Science Research Foundation of Zhejiang Health Bureau (grant nos. 2013KYA151 and 2016KYB024), Traditional Chinese Medicine Science and Technology Project of Zhejiang Province (grant no. 2016ZA024), National College Students Innovation and Entrepreneurship Training Program of China (grant no. 201513021011) and Zhejiang Provincial College Students' Science and Technology Innovation Project (grant no. 2015R401190).

\section{References}

1. Schultz MB and Sinclair DA: When stem cells grow old: Phenotypes and mechanisms of stem cell aging. Development 143: 3-14, 2016.

2. Brunauer R and Kennedy BK: Medicine. Progeria accelerates adult stem cell aging. Science 348: 1093-1094, 2015.

3. Miura Y: Guest editorial: Human mesenchymal stromal/stem cell (MSC). Int J Hematol 103: 119-121, 2016.

4. Asumda FZ: Age-associated changes in the ecological niche: Implications for mesenchymal stem cell aging. Stem Cell Res Ther 4: 47, 2013.

5. De Miguel MP, Fuentes-Julián S, Blázquez-Martínez A Pascual CY, Aller MA, Arias J and Arnalich-Montiel F: Immunosuppressive properties of mesenchymal stem cells: Advances and applications. Curr Mol Med 12: 574-591, 2012.

6. Ankrum J and Karp JM: Mesenchymal stem cell therapy: Two steps forward, one step back. Trends Mol Med 16: 203-209, 2010.

7. Alt EU, Senst C, Murthy SN, Slakey DP, Dupin CL, Chaffin AE, Kadowitz PJ and Izadpanah R: Aging alters tissue resident mesenchymal stem cell properties. Stem Cell Res 8: 215-225, 2012.

8. Ting $\mathrm{CH}$, Ho PJ and Yen BL: Age-related decreases of serum-response factor levels in human mesenchymal stem cells are involved in skeletal muscle differentiation and engraftment capacity. Stem Cells Dev 23: 1206-1216, 2014.

9. Khan M, Mohsin S, Khan SN and Riazuddin S: Repair of senescent myocardium by mesenchymal stem cells is dependent on the age of donor mice. J Cell Mol Med 15: 1515-1527, 2011.

10. Zhang DY, Wang HJ and Tan YZ: Wnt/ $\beta$-catenin signaling induces the aging of mesenchymal stem cells through the DNA damage response and the p53/p21 pathway. PLoS One 6: e21397, 2011.

11. Zhang E, Guo Q, Gao H, Xu R, Teng S and Wu Y: Metformin and resveratrol inhibited high glucose-induced metabolic memory of endothelial senescence through SIRT1/p300/p53/p21 pathway. PLoS One 10: e0143814, 2015. 
12. del Nogal M, Troyano N, Calleros L, Griera M, Rodriguez-Puyol M, Rodriguez-Puyol D and Ruiz-Torres MP: Hyperosmolarity induced by high glucose promotes senescence in human glomerular mesangial cells. Int J Biochem Cell Biol 54: 98-110, 2014

13. Güemes M, Rahman SA and Hussain K: What is a normal blood glucose? Arch Dis Child 101: 569-574, 2016.

14. Cheng NC, Hsieh TY, Lai HS and Young TH: High glucose-induced reactive oxygen species generation promotes stemness in human adipose-derived stem cells. Cytotherapy 18 : 371-383, 2016

15. Ferraro F, Lymperi S, Méndez-Ferrer S, Saez B, Spencer JA, Yeap BY, Masselli E, Graiani G, Prezioso L, Rizzini EL, et al: Diabetes impairs hematopoietic stem cell mobilization by altering niche function. Sci Transl Med 3: 104ra101, 2011.

16. Kočí Z, Turnovcová K, Dubský M, Baranovičová L, Holáň V, Chudíčková M, Syková E and Kubinová S: Characterization of human adipose tissue-derived stromal cells isolated from diabetic patient's distal limbs with critical ischemia. Cell Biochem Funct 32: 597-604, 2014.

17. Stolzing A, Coleman N and Scutt A: Glucose-induced replicative senescence in mesenchymal stem cells. Rejuvenation Res 9: 31-35, 2006.

18. Parsch D, Fellenberg J, Brummendorf TH, Eschlbeck AM and Richter W: Telomere length and telomerase activity during expansion and differentiation of human mesenchymal stem cells and chondrocytes. J Mol Med (Berl) 82: 49-55, 2004.

19. Estrada JC, Torres Y, Benguría A, Dopazo A, Roche E, Carrera-Quintanar L, Pérez RA, Enríquez JA, Torres R, Ramírez JC, et al: Human mesenchymal stem cell-replicative senescence and oxidative stress are closely linked to aneuploidy. Cell Death Dis 4: e691, 2013.

20. Liu S, Liu S, Wang X, Zhou J, Cao Y, Wang F and Duan E: The PI3K-Akt pathway inhibits senescence and promotes self-renewal of human skin-derived precursors in vitro. Aging Cell 10: 661-674, 2011.

21. Iglesias-Bartolome R, Patel V, Cotrim A, Leelahavanichkul K, Molinolo AA, Mitchell JB and Gutkind JS: mTOR inhibition prevents epithelial stem cell senescence and protects from radiation-induced mucositis. Cell Stem Cell 11: 401-414, 2012

22. Zhang D, Yan B, Yu S, Zhang C, Wang B, Wang Y, Wang J, Yuan Z, Zhang L and Pan J: Coenzyme Q10 inhibits the aging of mesenchymal stem cells induced by D-galactose through Akt/mTOR signaling. Oxid Med Cell Longev 2015: 867293, 2015.

23. Wang XM, Yao M, Liu SX, Hao J, Liu QJ and Gao F: Interplay between the notch and PI3K/Akt pathways in high glucose-induced podocyte apoptosis. Am J Physiol Renal Physiol 306: F205-F213, 2014.

24. Montes DK, Brenet M, Muñoz VC, Burgos PV, Villanueva CI, Figueroa CD and González CB: Vasopressin activates Akt/mTOR pathway in smooth muscle cells cultured in high glucose concentration. Biochem Biophys Res Commun 441: 923-928, 2013.

25. Guan G, Han H, Yang Y, Jin Y, Wang X and Liu X: Neferine prevented hyperglycemia-induced endothelial cell apoptosis through suppressing ROS/Akt/NF- $\kappa \mathrm{B}$ signal. Endocrine 47: 764-771, 2014.

26. Wakao S, Kuroda Y, Ogura F, Shigemoto T and Dezawa M: Regenerative effects of mesenchymal stem cells: Contribution of muse cells, a novel pluripotent stem cell type that resides in mesenchymal cells. Cells 1: 1045-1060, 2012.
27. Tomé M, Sepúlveda JC, Delgado M, Andrades JA, Campisi J, González MA and Bernad A: miR-335 correlates with senescence/aging in human mesenchymal stem cells and inhibits their therapeutic actions through inhibition of AP-1 activity. Stem Cells 32: 2229-2244, 2014.

28. Raggi $\mathrm{C}$ and Berardi AC: Mesenchymal stem cells, aging and regenerative medicine. Muscles Ligaments Tendons J 2: 239-242, 2012.

29. Rachmiel M, Cohen M, Heymen E, Lezinger M, Inbar D, Gilat S, Bistritzer T, Leshem G, Kan-Dror E, Lahat E and Ekstein D: Hyperglycemia is associated with simultaneous alterations in electrical brain activity in youths with type 1 diabetes mellitus. Clin Neurophysiol 127: 1188-1195, 2016.

30. Galindo RJ and Wallia A: Hyperglycemia and diabetes mellitus following organ transplantation. Curr Diab Rep 16: 14, 2016.

31. Kojima H, Kim J and Chan L: Emerging roles of hematopoietic cells in the pathobiology of diabetic complications. Trends Endocrinol Metab 25: 178-187, 2014.

32. Chang TC, Hsu MF and Wu KK: High glucose induces bone marrow-derived mesenchymal stem cell senescence by upregulating autophagy. PLoS One 10: e0126537, 2015.

33. Zhang DY, Pan Y, Zhang C, Yan BX, Yu SS, Wu DL, Shi MM, Shi K, Cai XX, Zhou SS, et al: Wnt/ $/$-catenin signaling induces the aging of mesenchymal stem cells through promoting the ROS production. Mol Cell Biochem 374: 13-20, 2013.

34. Liu L, Hu X, CaiGY,Lv Y,Zhuo L, Gao JJ, Cui SY,Feng Z, Fu B and Chen XM: High glucose-induced hypertrophy of mesangial cells is reversed by connexin43 overexpression via PTEN/Akt/mTOR signaling. Nephrol Dial Transplant 27: 90-100, 2012.

35. Gilardini Montani MS, Granato M, Cuomo L, Valia S, Di Renzo L, D'Orazi G, Faggioni A and Cirone M: High glucose and hyperglycemic sera from type 2 diabetic patients impair DC differentiation by inducing ROS and activating Wnt/ $\beta$-catenin and p38 MAPK. Biochim Biophys Acta 1862: 805-813, 2016.

36. Mehrfarjam Z, Esmaeili F, Shabani L and Ebrahimie E: Induction of pancreatic $\beta$ cell gene expression in mesenchymal stem cells. Cell Biol Int 40: 486-500, 2016.

37. Sun Y, Chen L, Hou XG, Hou WK, Dong JJ, Sun L, Tang KX, Wang B, Song J, Li H and Wang KX: Differentiation of bone marrow-derived mesenchymal stem cells from diabetic patients into insulin-producing cells in vitro. Chin Med J (Engl) 120: 771-776, 2007.

38. Hashemian SJ, Kouhnavard $M$ and Nasli-Esfahani E: Mesenchymal stem cells: Rising concerns over their application in treatment of type one diabetes mellitus. J Diabetes Res 2015: 675103, 2015.

39. Rekittke NE, Ang M, Rawat D, Khatri R and Linn T: Regenerative therapy of type 1 diabetes mellitus: From pancreatic islet transplantation to mesenchymal stem cells. Stem Cells Int 2016: 3764681, 2016.

40. Fadini GP, Sartore S, Schiavon M, Albiero M, Baesso I, Cabrelle A, Agostini C and Avogaro A: Diabetes impairs progenitor cell mobilisation after hindlimb ischaemia-reperfusion injury in rats. Diabetologia 49: 3075-3084, 2006

41. Shin L and Peterson DA: Impaired therapeutic capacity of autologous stem cells in a model of type 2 diabetes. Stem Cells Transl Med 1: 125-135, 2012. 